\title{
Developing government policies for distance education: lessons learnt from two Sri Lankan case studies
}

Article

Liyanagunawardena, T. R., Adams, A. A., Rassool, N. and Williams, S. A. (2014) Developing government policies for distance education: lessons learnt from two Sri Lankan case studies. International Review of Education, 60 (6). pp. 821 839. ISSN 1573-0638 doi: https://doi.org/10.1007/s11159-0149442-0 Available at https://centaur.reading.ac.uk/37267/

It is advisable to refer to the publisher's version if you intend to cite from the work. See Guidance on citing.

To link to this article DOI: http://dx.doi.org/10.1007/s11159-014-9442-0

Publisher: Springer

Publisher statement: The final publication is available at Springer via http://dx.doi.org/10.1007/s11159-014-9442-0

All outputs in CentAUR are protected by Intellectual Property Rights law, including copyright law. Copyright and IPR is retained by the creators or other copyright holders. Terms and conditions for use of this material are defined in the End User Agreement.

www.reading.ac.uk/centaur 


\section{CentAUR}

Central Archive at the University of Reading

Reading's research outputs online 


\title{
Developing government policies for distance education: Lessons learnt from two Sri Lankan case studies
}

\author{
Tharindu Rekha Liyanagunawardena $\bullet$ Andrew A. Adams $\bullet$ Naz Rassool $\bullet$ Shirley A. \\ Williams
}

\begin{abstract}
Education, especially higher education, is considered vital for maintaining national and individual competitiveness in the global knowledge economy. Following the introduction of its "Free Education Policy" as early as 1947, Sri Lanka is now the best performer in basic education in the South Asian region, with a remarkable record in terms of high literacy rates and the achievement of universal primary education. However, access to tertiary education is a bottleneck, due to an acute shortage of university places. In an attempt to address this problem, the government of Sri Lanka has invested heavily in information and communications technologies (ICTs) for distance education. Although this has resulted in some improvement, the authors of this article identify several barriers which are still impeding successful participation for the majority of Sri Lankans wanting to study at tertiary level. These impediments include the lack of infrastructure/resources, low English language proficiency, weak digital literacy, poor quality of materials and insufficient provision of student support. In the hope that future implementations of ICTenabled education programmes can avoid repeating the mistakes identified by their research in this Sri Lankan case, the authors conclude their paper with a list of suggested policy options.
\end{abstract}

Keywords distance education; e-learning; developing countries; policy perspective, Sri Lanka

Résumé ((The French translation of the edited version of the abstract will be added here later))

T. R. Liyanagunawardena ( $\square$ )

School of Systems Engineering, University of Reading, Whiteknights, Reading RG6 6AY, UK

e-mail: t.r.liyanagunawardena@reading.ac.uk

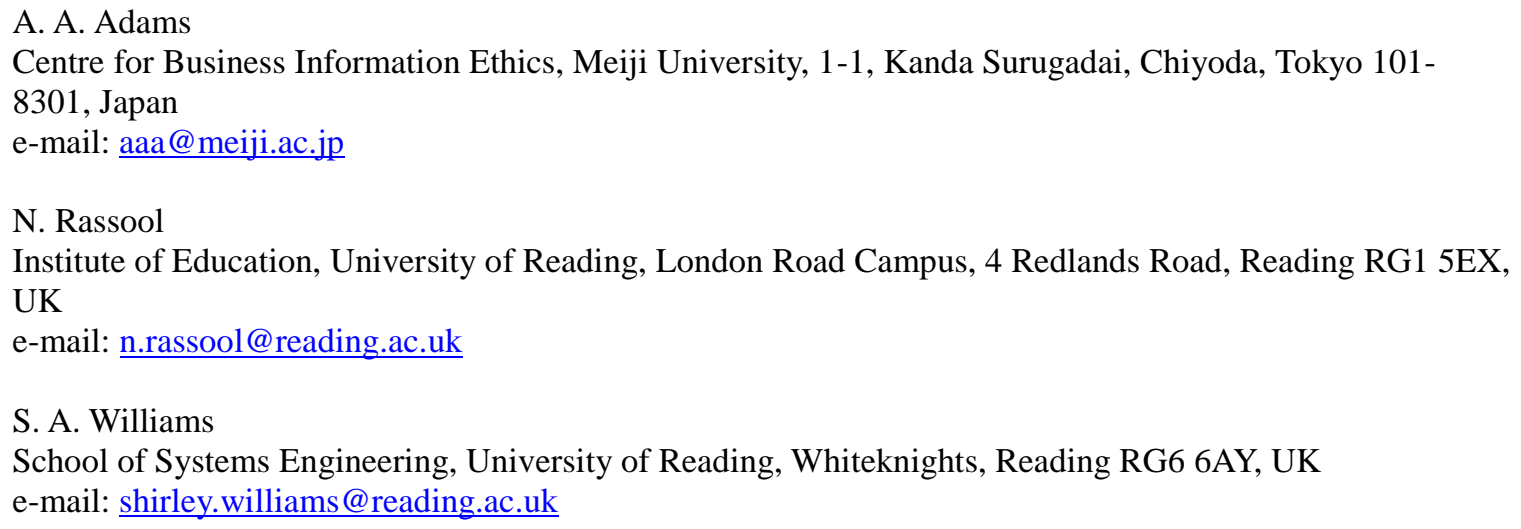




\section{Introduction}

Our contemporary world is experiencing an unprecedented pace of change. Much of this acceleration has been fuelled by the advance of technologies, globalisation, the growth of the knowledge economy and increasing global market competition. Within this context, knowledge has become a commodity within the international labour market and "economic advantage will accrue to countries in which the population acquires competence in processing information into knowledge and applying it in work and everyday life" (UNESCO 2002, p. 17). The redefined workplace requires new ways of working, relying to a significant extent on high skills and expert knowledge (Brown et al. 2001; Rassool 1999). In industrialised economies, both repetitive manual labour and simple information-processing tasks have either been automated or outsourced to developing economies (Klein 2002). Within this context, "knowledge workers" (Drucker 1970) have gained significance as a major source of labour. As knowledge has become an increasingly important factor, education, especially at higher levels, is considered vital for maintaining national and individual competitiveness. Furthermore, due to the rapid rate of knowledge creation, and more importantly, its short shelf-life in this new economy, there is a growing need for continuous skills updating and lifelong learning.

The global market created for higher education by the ratification of education as a tradeable service in the General Agreement on Trade in Services (GATS) ${ }^{1}$ has resulted in many private sector providers entering the higher education sector. Governments, especially in developing countries which had not previously allowed private providers to participate in the higher education sector have had little choice but to change their policies as they found themselves unable to afford the investment needed to create an adequate state higher education infrastructure to support the new educational market demands. The World Bank, which previously emphasised basic education and provided only ad-hoc support for tertiary educational development, is now actively promoting the

\footnotetext{
${ }^{1}$ Created by the World Trade Organization (WTO) for the purpose of removing legal obstacles to services trade, the General Agreement on Trade in Services (GATS), sometimes also referred to as the Uruguay Round Agreement, came into force in 1995 (WTO 1995)
} 
quality and relevance of tertiary education (World Bank 2002).

The opportunities offered by distance education, facilitating both part-time and fulltime study and reducing geographical constraints regarding travel and access, have come to be regarded by some as the most efficient expansion route for tertiary education. One of the major benefits of distance education lies in its potential for making knowledge and skills accessible to

indigenous peoples and others located in remote, rural areas who do not have convenient access to higher education institutions and where there is often a shortage of well-prepared teachers and other educational professionals (UNESCO 2002, p. 30).

As such, distance education potentially plays a significant role in bringing about equity and thus maximising human resource development, which, in turn, benefits the economic and social development of the country. Increasingly, information and communications technologies (ICTs) are being used in delivering distance education programmes because of a perception of lower costs and improved quality. ICT costs can be considered to have two components: costs to institutions and costs to learners. Potential advantages for learners are flexible access regarding time and location, a wide range of opportunities for learning and qualification and the facility to overcome cultural and social barriers as well as an inadequate physical educational infrastructure (UNESCO 2002). For example, the development of Massive Open Online Courses (MOOCs) ${ }^{2}$ has opened up learning opportunities from leading universities worldwide to a global audience (Liyanagunawardena et al. 2013c).

However, distance education (particularly if it is ICT-based) bears significant challenges of its own, and for some combinations of course structure, subject, learner situation and provider situation the desired access goals may either not be deliverable at all or prove to be more costly than increasing traditional face-to-face delivery. Whilst many governments in developing countries have stepped up opportunities for access to higher education through non-traditional forms of delivery such as distance education or

\footnotetext{
${ }^{2}$ Having emerged relatively recently (in the last six years ) on the distance learning scene, Massive Open Online Courses (MOOCs) are online courses aimed at unlimited participation - in some cases in open access format - via the Internet. Besides providing course materials such as texts, illustrations, videos etc., an important feature of MOOCs are interactive user forums.
} 
e-learning ${ }^{3}$, many of these new courses have been undermined because of their poor quality, which has resulted in high levels of dropout and/or failure to achieve any broadening of participation ${ }^{4}$ (despite this often being one of the primary goals of a programme). In the case of Sri Lanka, for example, it was acknowledged that the distance education degree courses offered by many of the state universities fell below the required standard (Kaye 2002).

\section{The higher education system in Sri Lanka}

Sri Lanka is the best performer in basic education in the South Asian region with a remarkable record in terms of high literacy rates and the achievement of universal primary education (Jayaweera and Gunawardena 2007; Riboud et al. 2007). This strong focus on initial education has come at the price of a relatively low proportion of the population entering higher education. In India, 47 per cent of Indians (aged 15 and over) were literate in 2000, while 4.7 per cent were educated above secondary level (Riboud et al. 2007); in Sri Lanka, in the same year, 91 per cent were literate, but just 2.3 per cent of adults aged 30+ (excluding the Northern and Eastern Provinces, which likely had an even lower rate due to civil war) had an education above secondary level (DoCS 2011a). The "Free Education Policy" of Sri Lanka, introduced in 1947, allows every child to access school education free of charge in state schools (up to the age of 19 years or the Advanced Level Exams - Year 13) and is also a primary contributor to Sri Lanka's current literacy rate. However, at tertiary level, state universities (currently the largest provider of higher education) have only around 22,000 places a year for new entrants (catering for just about 3 per cent of the school-leaving age cohort), albeit with no enrolment or tuition fees. Even though there are private higher education institutions, their high fees are beyond the financial means of most potential students. This acute shortage of affordable higher education opportunities in Sri Lanka creates fierce competition in the Advanced level General Certificate of Education (A-level GCE)

\footnotetext{
${ }^{3}$ The term e-learning (electronic learning) refers to an education process involving the use of ICTs for learning purposes.

${ }^{4}$ By the term broadening of participation, we mean opening up opportunities which draw in more students from lower socioeconomic backgrounds and rural areas, whereas the term increasing participation refers to a general rise of enrolments in absolute numbers.
} 
examination, which is also used for university entrance evaluations.

The University Grants Commission ${ }^{5}$ (UGC) of Sri Lanka uses a statistical method (Z-score) to standardise A-level results to evaluate candidates for university entrance (Kulatunga 2008). Furthermore, there are strict policies in place to ensure that candidates from all districts get a chance to enter university. Up to 55 per cent of the available places are allocated based on the ratio of population of the district to the population of the country, and there are special quotas for under-developed districts due to the lack of educational facilities in those districts (NEC 2009). These selection criteria are currently being revised ${ }^{6}$ since they are regarded as being unfair on students who have studied in districts considered to be "developed". With the exception of a few programmes which have aptitude tests, there is no means of entering the state universities governed by the UGC other than by obtaining the Z-score specified for intake. Students failing to secure a place in the state university system can seek higher education through the Open University of Sri Lanka (OUSL), external degrees (distance learning programmes) offered by some of the state universities or programmes offered by private institutions. Unlike state university face-to-face programmes, which are free, all these alternative courses can only be accessed by fee-paying students. Moreover, the majority of the courses offered in Sri Lankan universities (including courses in medicine, engineering, veterinary science and dentistry) are conducted only in English while school education is usually conducted in the local languages (Sinhala and Tamil) with English as a compulsory subject. For a comparative overview of the options, see Table 1.

Table 1 Comparative overview of undergraduate university education options in Sri Lanka

\begin{tabular}{|l|l|l|l|l|}
\hline institution & $\begin{array}{l}\text { terms of } \\
\text { admission }\end{array}$ & type & fees & $\begin{array}{l}\text { language of } \\
\text { instruction }\end{array}$ \\
\hline $\begin{array}{l}\text { state } \\
\text { universities } \\
\begin{array}{l}\text { Sri Lanka } \\
\text { currently has 18 }\end{array}\end{array}$ & $\begin{array}{l}\text { A-level GCE; } \\
\text { Z-score;** } \\
\text { a small number } \\
\text { of programmes }\end{array}$ & face-to-face & $\begin{array}{l}\text { no enrolment } \\
\text { or tuition fees } \\
\text { (in addition } \\
\text { many students }\end{array}$ & $\begin{array}{l}\text { most courses } \\
\text { are taught in } \\
\text { English }\end{array}$ \\
\hline
\end{tabular}

\footnotetext{
${ }^{5}$ The University Grants Commission (UGC) governs 15 of the 18 state universities. The remaining three, governed by the Ministry of Education, provide higher education opportunities for Buddhist clergy and armed force personnel.

${ }^{6}$ For current admission criteria see UGC 2013, p. 7.
} 


\begin{tabular}{|c|c|c|c|c|}
\hline \multirow[t]{2}{*}{$\begin{array}{l}\text { of these, with } 15 \\
\text { being open to } \\
\text { the public-see } \\
\text { footnote } 5 \text { ) }\end{array}$} & $\begin{array}{l}\text { have aptitude } \\
\text { tests; } \\
\text { regional quotas } \\
\text { to ensure equal } \\
\text { opportunities for } \\
\text { students from all } \\
\text { districts }\end{array}$ & & $\begin{array}{l}\text { receive } \\
\text { scholarships } \\
\text { or bursaries) }\end{array}$ & \\
\hline & $\begin{array}{l}\text { admission tests } \\
\text { and/or obtaining } \\
\text { necessary level } \\
\text { at A-level GCE* } \\
\text { (or approved } \\
\text { qualifications) }\end{array}$ & distance & $\begin{array}{l}\text { fees for } \\
\text { enrolment, } \\
\text { tuition and } \\
\text { examinations } \\
\text { apply }\end{array}$ & $\begin{array}{l}\text { mostly in } \\
\text { English } \\
\text { some distance } \\
\text { education } \\
\text { courses } \\
\text { provide } \\
\text { tuition while } \\
\text { others publish } \\
\text { a syllabus and } \\
\text { conduct } \\
\text { examinations } \\
\text { for which } \\
\text { students } \\
\text { prepare by } \\
\text { attending } \\
\text { private tuition } \\
\text { (Kaye 2002) }\end{array}$ \\
\hline $\begin{array}{l}\text { private } \\
\text { universities }\end{array}$ & vary & $\begin{array}{l}\text { face-to-face and } \\
\text { distance }\end{array}$ & high fees & $\begin{array}{l}\text { most courses } \\
\text { are taught in } \\
\text { English }\end{array}$ \\
\hline $\begin{array}{l}\text { Open } \\
\text { University of } \\
\text { Sri Lanka } \\
\text { (OUSL) }\end{array}$ & $\begin{array}{l}\text { necessary A- } \\
\text { level GCE* (or } \\
\text { approved } \\
\text { qualifications) } \\
\text { or completion of } \\
\text { foundation } \\
\text { courses }\end{array}$ & $\begin{array}{l}\text { distance with } \\
\text { some face-to- } \\
\text { face } \\
\text { components }\end{array}$ & $\begin{array}{l}\text { fees for } \\
\text { enrolment, } \\
\text { tuition and } \\
\text { examinations } \\
\text { apply (but are } \\
\text { nominal in } \\
\text { comparison to } \\
\text { private } \\
\text { universtities' } \\
\text { course offers) }\end{array}$ & $\begin{array}{l}\text { first year of } \\
\text { an } \\
\text { undergraduate } \\
\text { programme } \\
\text { may be } \\
\text { completed in } \\
\text { local } \\
\text { languages or } \\
\text { English but } \\
\text { from second } \\
\text { year onward } \\
\text { English- } \\
\text { medium is } \\
\text { mandatory }\end{array}$ \\
\hline
\end{tabular}

* Advanced level General Certificate of Education

** Z-score is a statistical method used by the University Grants Commission (UGC) of Sri Lanka to standardise A-level results to evaluate candidates for university entrance 
The Distance Education Modernization Project (DEMP)

The Distance Education Modernization Project (DEMP), funded by a loan from the Asian Development Bank (2003-2010), marked the dawn of the use of modern technology in distance education in Sri Lanka. Through the development/deployment of distance education technologies, it aimed to increase access to post-secondary education in Sri Lanka while improving the quality and relevance of teaching and learning. The project intended to facilitate online learning for at least 225,000 students (Loxley et al. 2003). This capacity was expected to double over the first 5 years of the project, and the project aimed to provide the opportunity of post-secondary education to 1.4 million additional students over a period of 18 years. DEMP consisted of three components:

(1) The Distance Education Partnership Programme. This focused on improving distance education programme content, quality and distribution. It also included the development of the National Distance Education Network (NDEN), which links OUSL centres with other public and private post-secondary institutions in order to share resources. Through this national network, online distance education programmes are made accessible to students, and partner institutes are able to use it to host their online distance education programmes. This service is called the National Online Distance Education Service (NODES).

(2) The Public Private Partnership Programme (PPP). The programme emphasised the sharing of resources between public and private educational institutions including matching grants for student stipends, sharing information, participation in a standardised accreditation system, providing access to online distance learning courses and involvement in sharing programmes with overseas universities (Loxley et al. 2003).

(3) The OUSL Capacity Enhancement Programme. This aimed to enhance and upgrade the OUSL's facilities and encourage staff development.

However, as in many other developing countries, the use of ICTs for instruction in Sri Lanka inevitably raises the question of affordability and accessibility of the programmes 
because computers and the Internet are not widely "accessible" (Liyanagunawardena et al. 2013a, 2013b, 2013d). In order to improve accessibility, an island-wide network of 26 telecentre facilities (NODES Access Centres, called NACs) was established, ${ }^{7}$ which was to provide access to students registered in online distance education programmes offered under DEMP.

\section{Method}

This paper addresses the policy issues arising from our research into the impact of ICTs on distance education in Sri Lanka. Using an ethnographic research approach, we investigated the implementation of ICT-enabled distance education programmes in two universities: Orange Valley University (OVU) and Yellow Fields University (YFU) (pseudonymous), which were both offering programmes under the DEMP initiative. We selected these two universities as our case studies because they differed in their approach to implementing ICT-enabled distance education and in their experience in distance education.

OVU had been a conventional university until it implemented its fully-online distance education degree programme, while YFU has been teaching distance learners for many years, offering a variety of programmes (certificates, degrees, higher degrees, etc.). YFU introduced ICTs to its distance education spectrum more cautiously than OVU, with many programmes having non-compulsory online components and very few having compulsory online components. Thus our comparative approach would provide a good view of the range of ICT-enabled distance education implementations in programmes. All data collection was carried out between December 2009 and March $2011^{8}$.

The sample population for these two case studies included students, lecturers and administrators of these universities. Our research project was advertised through official channels and participation was voluntary. Because OVU had only one programme under this initiative, which was an IT programme, we selected a comparable IT programme

\footnotetext{
7 This network was set up in addition to the telecentres owned by "Sarvodaya" (a non-governmental organisation) and the approximately 700 Nanasala centres established under the government's eSri Lanka initiative.

${ }^{8}$ Subsequent to our data collection, the fully-online provision of OVU's distance education programme was discontinued.
} 
from YFU's range of programmes for our survey.

Besides carrying out these two case studies, we also interviewed carefully selected people from policy authorities (National Education Commission, University Grants Commission, and the Ministry of Higher Education), DEMP officials and university officials to obtain a holistic view of the initiative at policy level, implementation level and end-user level.

To collect our data, we used semi-structured interviews (with officials, students and lecturers), documentary evidence (student registration details, NAC usage statistics and Learning Management System activity logs) and self-completion questionnaires (for students). The reason we opted for semi-structured interviews was that they provided general guidelines to carry out the interview with flexibility to generate rich qualitative data through probing. The interviews, which were audio recorded and transcribed, were conducted either in English or in Sinhala, depending on the participant's preference.

Questionnaires were employed to gather views from a wider sample and to invite interested participants for interviews. At an early stage we realised that an online survey (using the Bristol Online Surveys tool) ${ }^{9}$ prepared for the study was taking too long to load and this discouraged participation. Thus only e-mail and printed questionnaires were actually employed for our data collection. We decided to present the questionnaire in Microsoft ${ }^{\circledR}$ Word 2003 format, since it was unlikely that newer versions of this software would be available in most Internet cafés and on Sri Lankan home computers. The e-mail questionnaires were only distributed in English since the Unicode Sinhala fonts used for the questionnaire might not have been available on recipients' computers, especially on public Internet access points where users do not have privileges to install fonts. Printed questionnaires were distributed in both English and Sinhala, according to each participant's preference. Questions were organised into five sections: (1) programme details; (2) the use of ICT in the programme and student views; (3) the use of ICTs for learning; (4) opportunities for using ICTs (with space provided for comments at the end of the section); and (5) demographic details.

The rationale for employing documentary evidence as a data source in this study

\footnotetext{
${ }^{9}$ Created by the University of Bristol, UK, the online survey tool "Bristol Online Surveys (BOS) is an easy-to-use service that allows you to develop, deploy, and analyse surveys via the Web. No complicated set-up or technical knowledge is required" (http://www.survey.bris.ac.uk/support/about).
} 
was to supplement data collected from other sources. For example, activity logs provide time series data of learning environment use by students, which can be analysed along with students' statements of use in order to complement data obtained using questionnaires and interviews.

In total 129 questionnaires, 33 individual interviews and 2 group interviews were used for the analysis. Our data collection summary is presented in Table 2.

Table 2 Summary of data collection

\begin{tabular}{|l|c|c|c|}
\hline & Questionnaires & Interviews & $\begin{array}{c}\text { Group } \\
\text { interviews }\end{array}$ \\
\hline $\begin{array}{l}\text { Orange Valley University } \\
\text { (OVU) }\end{array}$ & 33 & 14 & 1 \\
\hline $\begin{array}{l}\text { Yellow Fields University } \\
\text { (YFU) }\end{array}$ & 96 & 13 & 1 \\
\hline Education policy authorities & no & 6 & no \\
\hline Total & 129 & 33 & 2 \\
\hline
\end{tabular}

\section{Results}

In the following section, we present our results organised by the following aspects: population demographics (enrolled students); sample demographics, computer ownership and Internet access; household income; access centres; cost, language, computer proficiency; and learning materials and learner support.

Population demographics

Population demographics of the OVU fully-online programme showed that 39 per cent of the students enrolled in the programme were female. The comparable YFU IT programme only had 26 per cent females. Female participation in the Sri Lankan IT industry is only 21 per cent (ICTA 2007); therefore the female participation rate in both programmes was encouraging, especially when compared with developed economies such as the UK, where men outnumber women 5:1 in the IT sector (Pretorius and de Villiers 2009).

Exactly one half of OVU students were from the Western Province (the capital Colombo and the surrounding area), while in the YFU IT programme their share was as 
high as 83 per cent. Considering that only 28 per cent of the Sri Lankan population resides in the Western Province (DoCS 2010), both these programmes seem primarily to serve the needs of Western Province dwellers. There are several plausible explanations. Since the YFU IT programme recruited students with work experience in the IT industry, it is likely that these distance learners were working in Colombo or the Western Province (even if they originated from elsewhere in the country), because the IT industry in Sri Lanka is mostly concentrated in these areas. Another possibility is that since both these programmes were advertised as "online" degrees (even though the YFU programme's compulsory online component in fact only amounted to roughly 20 per cent of the course as a whole), only people who had ready access to the Internet and computers registered, resulting in an over-representation of students from the Western Province.

Sample demographics

Our OVU sample consisted of 33 per cent females, while the whole of the YFU sample (including students from IT, Science, Technology and Engineering programmes) consisted of 46 per cent females. Our comparison of sample gender distribution is illustrated in Fig 1.

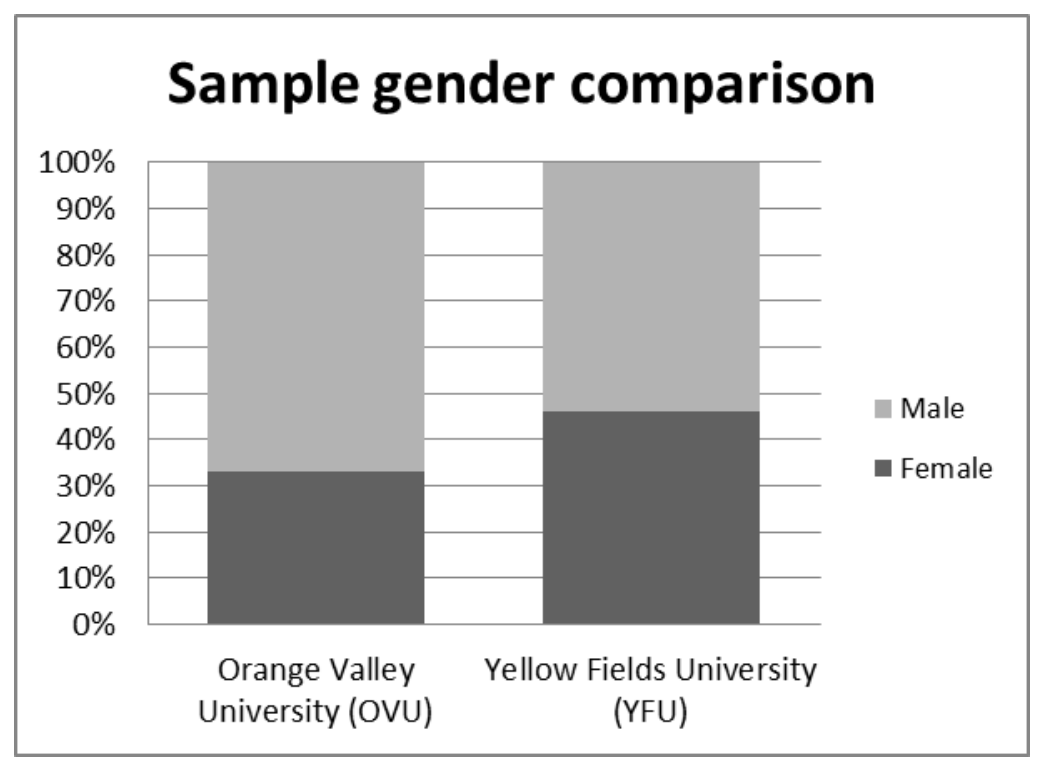

Figure 1 Sample gender comparison 
Sixty-seven per cent of the OVU sample were from the Western Province; in the YFU sample the corresponding figure was 54 per cent. A comparison of sample geographic distribution is presented in Fig 2. YFU has teaching/learning centres around the country and questionnaire data were collected on four occasions ( 3 at a Colombo centre, 1 at a regional centre). This could be a reason for the increased number of students from outside the Western Province in the sample.

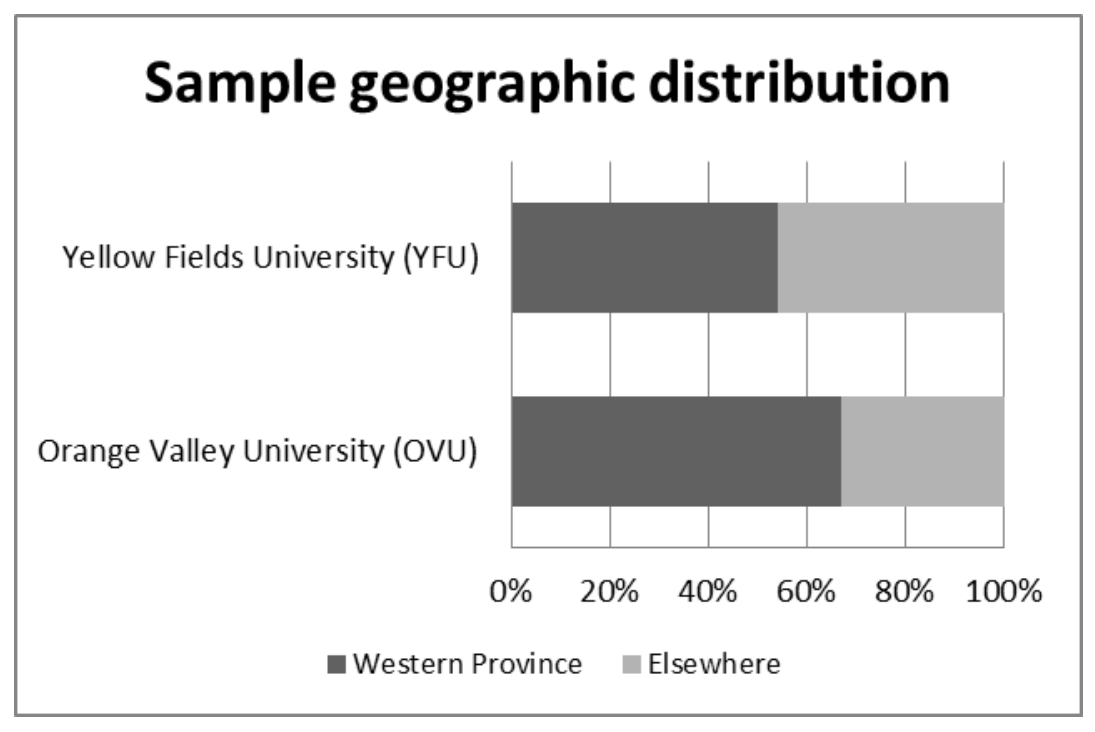

Figure 2 Sample geographic distribution

Computer ownership and Internet access

The ownership of computers among participants of both universities (OVU: 85\% and YFU: 68\%) was much higher than the Sri Lankan national average of 11.4 per cent in 2009 (DoCS 2009), as illustrated in Fig 3. 


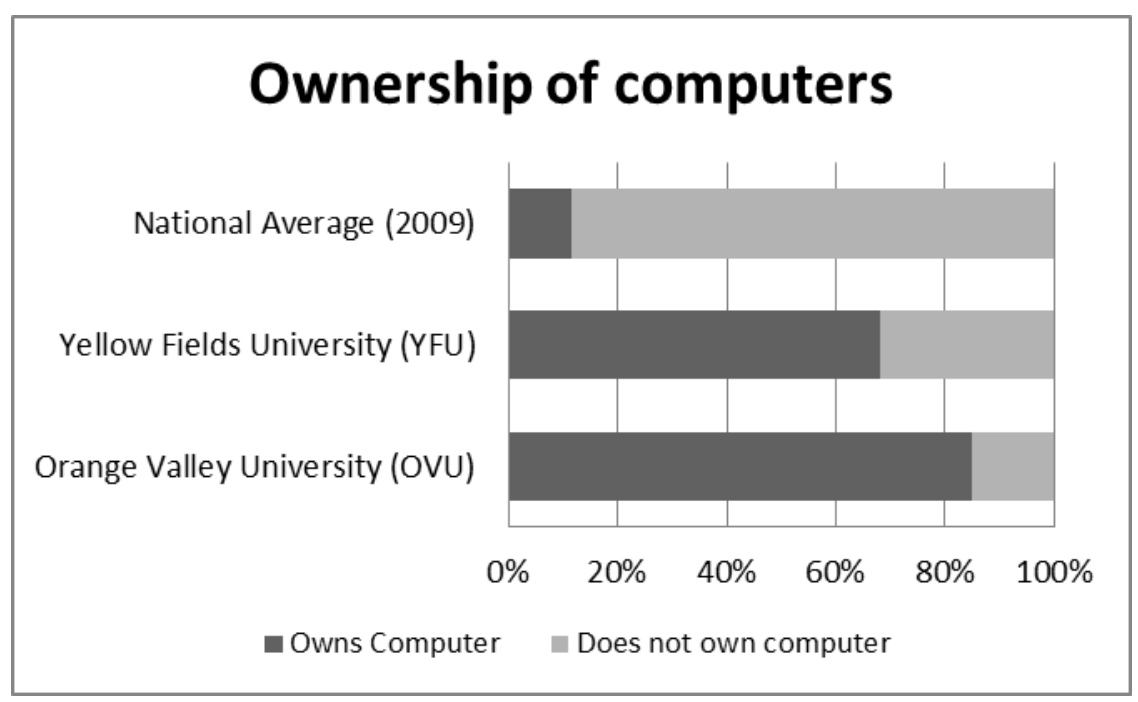

Source for national average data: DoCS 2009, Table 1

Figure 3 Comparison of computer ownership

Ninety-one per cent of OVU and 45 per cent of YFU student participants had home Internet access (some students who did not have home computers accessed the Internet using their mobile phones). There were YFU students, especially from rural and/or lowincome groups who solely depended on either NACs or University computer laboratories. By contrast, many OVU students who previously depended on NACs later decided to acquire their own home connections due to the difficulties they had had to face in using communal facilities.

Household income

The median monthly household income for the OVU sample was Rs 34,376 (£ 191); in the YFU sample it was Rs 22,709 (£ 126). A comparison of student household incomes against the national median household income Rs 23,746 (£ 135) (DoCS 2011b) is shown in Fig 4. Sixty-three per cent of the OVU students came from households earning more than the national median household income, which partly explains the very high level of resource ownership among OVU students. 


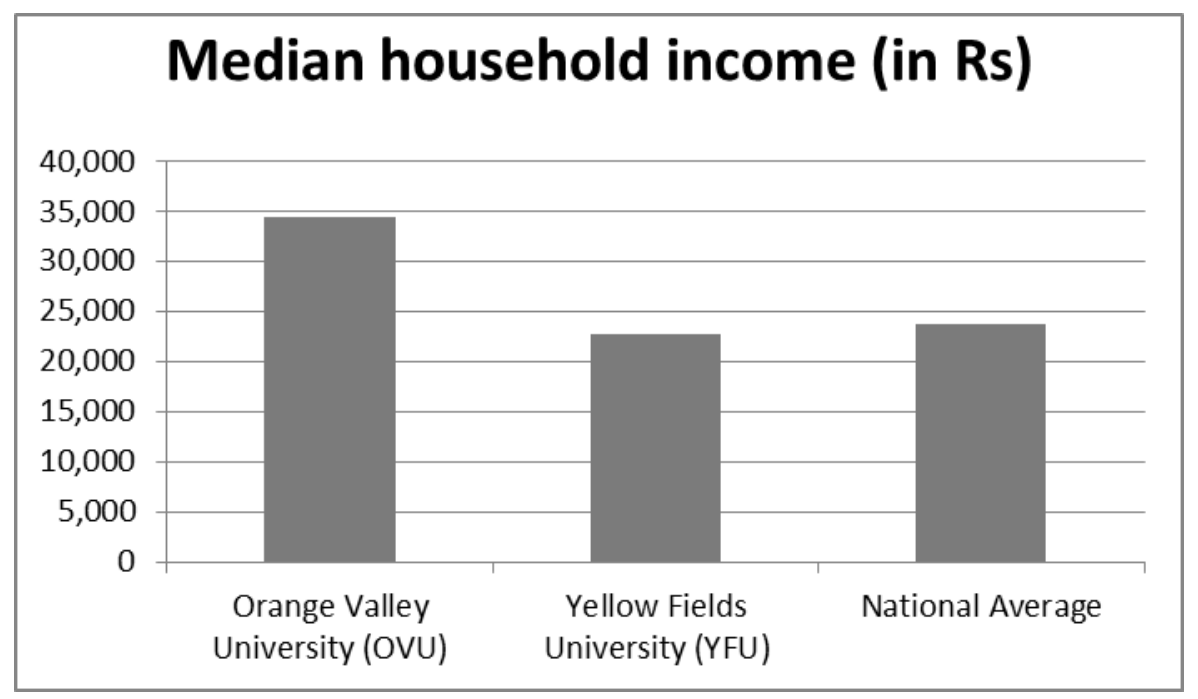

Source for national average data: DoCS 2011b, Table H1

Figure 4 Comparison of median household income (in Rs)

Students who depended on communal access had to spend a considerable amount of time travelling to their closest centre to access the Internet. For example, an undergraduate from Kandy had to take several buses, taking an hour and half on the bus (not considering the waiting times for buses) to use the nearest access centre; ${ }^{10}$ another student from a remote village in Hambantota which had no fixed-line or mobile broadband coverage (as of 2010), had to travel at least $60 \mathrm{~km}$ to the nearest NAC at Ambalantota. He used a mobile broadband connection to access the Internet while boarded in Colombo but criticised his provider for not delivering value for money.

\section{Access centres}

The NACs provided a valuable service to students who did not have computers and/or connectivity to the Internet. However, the excessive administrative procedures and their closure at the weekend were major problems (especially for employed students). One interview participant was asked to produce a letter from the Vice Chancellor of his university in order to have access to headphones to listen to a video lecture, while another said that there was no facility to use a "pendrive" (USB memory stick) to store

\footnotetext{
${ }^{10}$ This access centre was a regional centre of her university, the nearest NAC was even more distant.
} 
downloaded content. Another student studying for an IT degree, who wanted to use software which was not installed on the NAC computers, was unable to obtain permission to install it. The policy to block some websites such as YouTube ${ }^{\mathrm{TM}}$ was also a problem for students, who only had access to the Internet from NACs and wanted to use YouTube ${ }^{\mathrm{TM}}$ for educational purposes, specifically to watch YouTube ${ }^{\mathrm{TM}}$ videos relating to product designs similar to what they were designing (for more details see Liyanagunawardena et al. 2013a; 2013b).

NAC usage statistics showed that some of the centres are greatly underutilised. For example, Anuradhapura NAC was used by only one individual from August to October 2009 (Liyanagunawardena 2012). By contrast, Colombo and Kandy NACs were heavily utilised. Because all these centres were equipped with the same set of equipment, while some resources were idling in remote locations, users in other centres had restrictions in terms of access times, to ensure fair access for all. Due to all these reasons, respondents who had used NACs felt it was difficult to solely rely on them and bought their own computers and connectivity as soon as they could.

Cost

OVU's online educational course offer was considered "pricey" by almost all participants; yet students registered for it due to the university's good reputation. Personal communications revealed that a large proportion of the fee went into the university's payment to the NODES to get NAC access to course registrants. Even students who never used a NAC facility had to pay this fee since it was bundled into their course fee. By contrast, students felt that YFU's course offers were "value for money" and "affordable". This could also be a reason why a majority of students from the OVU online programme were from high-income households while YFU programmes were more attractive to students from low-income households.

\section{Language}

YFU students' English language skills varied widely, with students from Colombo 
demonstrating a higher level of English proficiency than their peers from more rural regions On the other hand, OVU students reported above-average English language proficiency. Even though English is taught as a compulsory subject in the school curriculum, the resources to learn English vary widely among urban and rural schools. For example, a YFU student who had studied in a rural school blamed the lack of resources and lack of motivation for the lower standard of English learning in rural areas. According to tutors/lecturers, a majority of the students from "outstations" (away from Colombo), who had studied the school curriculum in local languages found it difficult to adjust to English-medium instruction at university. Despite all OVU students rating their level of English as above average, OVU's interview participants speculated that some students, especially those from rural areas like Madawachchiya, dropped out of programmes due to difficulties they encountered in understanding English-medium instruction. It is worth noting that our questionnaire only reached those students who had remained in the programme for the third year, and it is possible that students with weak in English already dropped out earlier.

\section{Computer proficiency}

Our questionnaire listed four tasks relating to computer/Internet use, and the respondents' ability to accomplish those tasks was interpreted as their computer proficiency. All OVU respondents reported very high levels of computer skills. This was not surprising, since these students were in the upper years of an IT degree. YFU students also had adequate general computer skills. However, 9 per cent of the YFU respondents had never used a search engine; 5 per cent had never sent an e-mail with an attachment. Two per cent of the YFU participants had never used or did not want to use a computer. There was one student, a 25-year-old female teacher from Badulla, who reported that she did not know how to use the computer facilities available to her. Tutors of both universities have observed some students having difficulties even with basic computer skills. For example, one tutor from OVU (where students reported very high levels of computer skills) mentioned a student who, in an inaugural session held to introduce the online learning platform, was not aware of how to type an “@” sign. 
There was no uniform way of introducing the online learning platform to students. OVU organised a workshop for all new entrants; by contrast, at YFU it was the individual lecturer's responsibility. While some organised inaugural hands-on sessions or a lecture with a projection screen, others relied on a letter sent out to students which described the logging-in process. But many students were unable to comprehend this information on their own, even just to log into the system.

Even though our survey showed that most OVU students had good English language skills and good computer skills, it is worth noting that there was a very high dropout rate (out of the cohort of 98 students who registered in 2007, only 36 remained with the same cohort after 3 years) and the sample we were able to reach was made up of students who remained in the programme. It is likely that students who had poor English skills and/or poor computer skills had already dropped out from the programme by the time we conducted our research.

Learning materials and learner support

We also found there were issues relating to online learning materials. Some lecturers initially had doubts as to why their material needed reviewing by others, including other lecturers and pedagogic experts, showing that there was a lack of knowledge and understanding of distance education practices among OVU staff. Students reported instances where they posted questions online and had to wait for weeks to receive a reply. There were also issues with the learning materials: some were erroneous; others were copied from unreliable Internet sources such as Wikipedia (with no mention of the source); most of the time online course materials were text-only portable document format (PDF) notes; and in instances where online quizzes were employed, these either posed the same questions on each and every attempt, or students had to re-take online quizzes due to poor connection quality. OVU distance-learning students did not have access to university library facilities, ${ }^{11}$ in contrast to their counterparts at YFU. Thus they had to solely rely on provided course notes and free online resources unless they could afford to pay a premium for library membership at the British Council or similar

\footnotetext{
${ }^{11}$ OVU library facilities were only accessible to face-to-face/physically on-campus students.
} 
institutions. Because some notes provided to students contained errors, and tutors took a while to answer queries about them, many students were frustrated.

DEMP had greatly overestimated both the number of students who would register for the programme and the fee chargeable to a student for the use of NAC facilities. In the wake of the project (which ended in 2010), this has resulted in an infrastructure which is not economically viable. One can see many similarities between DEMP and the African Virtual University project ${ }^{12}$, which has also been criticised for its high cost, limited accessibility, and limited sustainability (Amutabi and Oketch 2003; Munene 2007).

\section{Discussion}

The goal of the Sri Lankan government was to increase participation in higher education. Their great success following educational investment at primary and secondary levels has led to a logjam at the tertiary level. An unwillingness to introduce fees for the majority of students, combined with a lack of funding to quickly increase face-to-face teaching and learning capacities, led the Sri Lankan government to invest in an ICT-enabled distance education approach. This did lead to some improvements, but was hampered by the reliance on ICTs and a one-size-fits-all approach. Instead of being monolithic, the plan consisted of two initiative approaches: (1) funding the development of ICT-based distance education programmes to complement course offers of existing face-to-face universities (an example of this is OVU); and (2) funding the "modernisation" of existing distance education programmes with ICTs (an example of this is YFU). Within the goal of increasing participation, there was also a desire to broaden (or at least to retain the existing level of) participation among students coming from outside the privileged social class. Our study identified clear flaws in the approach, which should be noted by the Sri Lankan government in future policies and should also be carefully studied by other developing countries investing in expansion of their higher education sector in order to compete in the global knowledge economy.

Many of our findings have been corroborated by the Asian Development Bank, who found DEMP to be "highly relevant" to Sri Lanka's strategies and vision but admitted

\footnotetext{
${ }^{12}$ For more information on the African Virtual University project, see http://www.avu.org/.
} 
that the project had been "less effective", "less efficient" and "less likely sustainable" than expected (ADB 2011).

The successes of ICT-based distance education

Existing high-quality programmes from high-prestige universities (such as OVU), are viable for quick and cheap expansion based on fee-paying students. The benefits to students are twofold. First, there is the chance of an education where before they had no opportunity to follow their preferred subject in their preferred location/university. Second, the ability to study flexibly, whether part-time or full-time, also in terms of credits, allows for the maintenance of family ties and of employment. The work-study option is particularly important in bootstrapping the system based not on post-graduation fee-loan repayment but on upfront ongoing fee payment. The most successful students are those in urban areas with access to Internet infrastructure and sufficient income to pay fees, purchase computers and subscribe to a broadband Internet connection. Initial problems with the development of the courses seem to be rectifiable, given appropriate oversight of the system and this more focused student body.

Mainly, it seems, due to the cost of supporting NACs, the OVU online programme was discontinued (Liyanagunawardena 2012). Without that cost, students enrolled in any distance learning course are left to provide their own resources. However, this also means that those with the resources are then not paying twice, particularly since an analysis reported elsewhere (Liyanagunawardena 2012) shows that NAC charges are actually almost similar in cost to lower-range Internet access packages. The potential additional cost is of having to buy a PC, but this investment can then also benefit other household members when they share the computer with the student.

The failures of ICT-based distance education

Many of the failures of ICT-based distance education are due to circumstantial disadvantages which are not sufficiently taken into account by some course providers. Many students based in rural areas are lacking in one or more of the following:

- Access to the Internet: some areas are not served by any service provider and for 
those which are, the costs are often higher, for worse service, than in urban areas.

- Incomes are too low to support purchase of suitable computers and subscription to the Internet even where service is available.

- English-based tuition is too much of a step up for those previously educated in Sinhala or Tamil and who were educated in schools with few resources for English learning.

- Central provision of computer centres is too inflexible on too many axes to provide substantial access across the geographic regions.

- $\quad$ Prior computer skills are lacking in those from rural areas, which poses particularly severe difficulties for those also lacking good proficiency in English.

Other reasons for failure which emerged from our research were:

- $\quad$ The lack of support services provided by the educational institutions for students starting online education in distance-learning mode.

- $\quad$ The lack of knowledge and awareness of lecturers/tutors in terms of providing online support for students.

- $\quad$ Poor quality and poor presentation of some course materials.

- $\quad$ The non-availability of library facilities for distance learners.

- The question of sustainability of the system.

Policy options

There is a need to:

- Allow high-prestige universities in urban areas to offer flexible courses, with clear monitoring of quality. Require the courses to have the same standards as face-toface courses for examinations. Possibly remove the requirement of distinguishing between face-to-face and distance education programmes, and perhaps even apply identical assessment criteria and degree course names. Invest in these high-prestige universities to help with start-up costs, but place them under the obligation to move on to self-sustaining fees. Possibly offer ongoing government-funded bursaries for students from poor urban backgrounds with just-missed levels of educational 
attainment for face-to-face courses (or even for those who achieved the relevant level, but not for the course they wanted or the location they wanted/needed). This should hopefully reduce the number of students taking up face-to-face places for which they are not entirely suited (our study revealed that a significant number of students on the new distance learning programmes offered by OVU were also studying a different subject on a face-to-face programme at another state university).

- Stipulate the provision of library facilities, both online and physical, for true distance learning students by enforcing mutual deals with universities in different cities providing library and perhaps computer-lab resources in return for allowing them to run their own online courses or perhaps by allocating part of the student's fee to pay a convenient institution for access.

- $\quad$ Focus on enhancing the existing OUSL distance education provision for widening participation. It already has the expertise and structure to offer courses in rural areas, starting with Sinhala/Tamil study combined with English proficiency enhancement, and uses a mixed ICT/non-ICT approach which also suits those without significant prior computer skills and/or access. For areas where it is feasible, instead of NACs invest in providing equipment and (probably wireless) broadband access for students as part of the fee structure - this needs careful economic analysis for each region. Consider the provision of cheaper mLearning ${ }^{13}$ options such as low-cost video/media-players which can replace time-specific broadcasts on TV of existing and updated visual material with anytime, anywhere access. Materials can be downloaded in bulk to such players during irregular visits to Internet-connected sites or sent out on hard storage devices (e.g. CDs, DVDs etc.) and passed around among students by post or through face-to-face contact.

- $\quad$ Stipulate cross-compatibility and open up upper-year entry between OUSL

\footnotetext{
${ }^{13}$ The term m-learning, slightly newer than the term e-learning, stands for mobile learning. This mode of learning can involve the use of various comparatively small mobile electronic devices such as handheld computers, MP3 players, notebooks, mobile phones and tablets.
} 
programmes and other distance education programmes. In particular, allowing those lacking English and computer skills to complete the OUSL foundation years and then proceed to the other programmes would perhaps be the best structural option.

\section{Conclusion}

Under the right circumstances, ICT-enabled distance education programmes have the potential to increase access to higher education by providing flexibility for the learner. Due to many reasons, including lack of infrastructure/resources, lack of English language skills and digital literacy, poor quality of materials and insufficient support provided to students, the present implementation of the system in Sri Lanka has been less than successful in recruiting a sufficient number of students to be able to self-sustain the system. It is particularly important for governments to research the real constraints on students to whom they wish to provide access to higher education. Furthermore, governments need to align new programmes with targeted structures which allow students to succeed, while providing suitable investment for providers to produce financially and academically sustainable programmes. It is clear from this Sri Lankan case study that broadening participation (including students from all socioeconomic regional backgrounds) and increasing participation (in absolute numbers) may require very different structures.

Acknowledgement The first author would like to thank the University of Reading, $\mathrm{UK}$, for the PhD studentship she received.

\section{References}

Amutabi, M. N. \& Oketch, M.O. (2003). Experimenting in distance education: The African Virtual University (AVU) and the paradox of the World Bank in Kenya. International Journal of Educational Development, 23(1), 57-73.

ADB (Asian Development Bank) (2011). Completion Report - Sri Lanka: Distance Education Modernization Project. Asian Development Bank.

Brown, P., Green, A. \& Lauder, H. (2001). High skills: Globalization, competitiveness 
and skill formation. Oxford: Oxford University Press.

DoCS (Department of Census and Statistics) (2009). Computer literacy in Sri Lanka 2009. Department of Census and Statistics Newsletter, 1(1). Colombo: Department of Census and Statistics.

DoCS (Department of Census and Statistics) (2010). Estimated mid-year population by sex and district - 2010. Colombo: Department of Census and Statistics.

DoCS (Department of Census and Statistics) (2011a). Social Conditions of Sri Lanka. Colombo: Department of Census and Statistics. Accessed 22 February 2014 from http://www.statistics.gov.lk/social/social\%20conditions.pdf.

DoCS (Department of Census and Statistics) (2011b). Household income and expenditure survey - 2009/10 final results. Household Income and Expenditure Survey. vol. 11

(March 2011). Colombo: Department of Census and Statistics.

Drucker, P. F. (1970). The effective executive. London: Pan Books.

ICTA (Information and Communication Technology Agency) (2007). Rising demand: The increasing demand for IT workers spells a challenging opportunity for the IT industry. Colombo: Information and Communication Technology Agency of Sri Lanka.

Jayaweera, S. \& Gunawardena, C. (2007). Social inclusion: Gender and equity in education swaps in South Asia - Sri Lanka Case Study. UNICEF Regional Office South Asia. Kathmandu: UNICEF.

Kaye, A. R. (2002). The current situation of external degrees in Sri Lanka: A Personal assessment based on a visit to Sri Lanka. S.l.: Commonwealth of Learning.

Klein, N. (2002). No Logo. New York: Picador.

Kulatunga, D. (2008). Education guide: Sri Lanka, 3rd edn. Battaramulla, Colombo: Neptune Publications.

Liyanagunawardena, T. R. (2012). Information communication technologies and distance education in Sri Lanka: A case study of two universities. PhD Thesis, University of Reading, Reading, UK.

Liyanagunawardena, T.R., Adams, A.A., Rassool, N. \& Williams, S.A. (2013a). Using non-personal computers for e-learning: Sri Lankan Experience. Journal of Education and Training Studies, 1(2), 152-158.

Liyanagunawardena, T., Adams, A. , Rassool, N. and Williams, S. (2013b). Telecentres and e-learning. British Journal of Educational Technology, 44(5), E156-E158.

Liyanagunawardena, T. R., Adams, A. A. \& Williams, S. (2013c). MOOCs: A systematic study of the published literature 2008-2012. International Review of Research in Open and Distance Learning, 14(3), 201-227.

Liyanagunawardena, T.R., Williams, S. \& Adams, A.A. (2013d). The impact and reach of MOOCs: A developing countries' perspective. eLearning Papers, 33 (Special Issue MOOCs and Beyond).

Loxley, W., Ho, S., Vandenabeele, C., Gutierrez, L. et al. (2003). Report and recommendation of the president to the Board of Directors on a proposed loan to the Democratic Socialist Republic of Sri Lanka for the distance education modernization project. Manila: Asian Development Bank.

Munene, I. I. (2007). Experimenting in distance education: The African Virtual University (AVU) and the paradox of the World Bank in Kenya - A Rejoinder. International Journal of Educational Development, 27(1), 77-85. 
NEC (National Education Commission) (2009). National policy framework on higher education and technical and vocational education. Colombo: National Education Commission.

Pretorius, H.W. \& de Villiers, C. (2009). An analysis of the international discourse about women in information technology. In Proceedings of the Annual Research Conference of the South African Institute of Computer Scientists and Information Technologists (pp. 179-186),.New York: Association for Computing Machinery (ACM).

Rassool, N. (1999). Literacy for sustainable development in the age of information, Multilingual Matters Ltd., Clevedon.

Riboud, M., Savchenko, Y., \& Tan, H. (2007). The knowledge economy and education and training in South Asia. Washington, D.C.: World Bank.

UNESCO (United Nations Educational, Scientific and Cultural Organization) (2002). Open and distance learning: Trends, policy and strategy considerations. Paris: UNESCO.

UGC (University Grants Commission) (2013). Admission to undergraduate courses of the universities in Sri Lanka. Academic year 2013/2014 (based on the G.C.E. (A/L) examination 2013). Colombo: UGC Sri Lanka. Accessed 25 July 2014 from http://www.ugc.ac.lk/downloads/admissions/local_students/Admission\%20to\%20U ndergraduate \%20Courses \%20of\%20the \%20Universities\%20in\%20Sri\%20Lanka\% 202013_2014.pdf.

World Bank (2002). Constructing knowledge societies: New challenges for tertiary education. Washington, D.C.: World Bank.

WTO (World Trade Organization) (1995). General agreement on trade in services (GATS). Geneva: WTO. Available online at http://www.wto.org/english/docs_e/legal_e/26-gats_01_e.htm.

\section{The authors}

Tharindu Rekha Liyanagunawardena is a Postdoctoral Research Assistant in the Computing Research Group - School of Systems Engineering at the University of Reading, UK. Her principal research interest lies in the area of social implications of information and communication technologies, especially eLearning. She completed her $\mathrm{PhD}$ (titled "Information Communication Technologies and Distance Education in Sri Lanka: a case study of two universities") at the University of Reading in 2012. She is cocreator and lead facilitator of the "Begin Programming: build your first mobile game", a popular Massive Open Online Course (MOOC) on the FutureLearn platform. Currently she is working on several projects relating to Open Educational Resources (OERs) and MOOCs.

Andrew A. Adams is a Professor of Information Ethics in the Graduate School of Business Administration and Deputy Director of the Centre for Business Information Ethics at Meiji University in Tokyo, Japan. He is also a Visiting Professor in the School of Systems Engineering at the University of Reading in the UK. He has a wide range of 
research interests in multi-disciplinary fields looking into social, legal and ethical aspects of computing.

Naz Rassool is a Professor of Education at the Institute of Education, The University of Reading. She has published widely within the fields of the political economy of language in education; literacy and development; language relations within the global cultural economy; New Managerialism in education and the sociology of technology in education. She is the author of Global Issues in Language, Education and Development:

Perspectives from Postcolonial Countries (2007); Literacy for Sustainable Development in the Age of Information (1999); co-author with Louise Morley of School Effectiveness: Fracturing the Discourse (1999) and co-edited with Kevin Brehony of Nationalisms Old and New (1999).

Shirley A. Williams is a National Teaching Fellow and a Professor of Learning Technologies at the University of Reading, UK. She is also an Honorary Professor at University College London. She is currently involved in a number of research projects related to learning technologies, communities, social networks, digital identity and knowledge transfer. She is the Director of Open Online Courses at University of Reading, the University is a Futurelearn partner. 